\title{
Probiotics: Helpful for the prevention of COVID-19?
}

\author{
Nishat Zafar ${ }^{1, * 0}$, Muhammad Aamir Aslam ${ }^{1}$, Ashiq Ali ${ }^{2}$, Aisha Khatoon ${ }^{2}$, Abdul Nazir ${ }^{3}$, Qaisar Tanveer ${ }^{4}$, \\ Muhammad Bilal ${ }^{5}$, Rabia Kanwar ${ }^{1}$, Azka Qadeer ${ }^{1}$, Muhammad Sikandar ${ }^{6}$, Abdullah Zafar ${ }^{1}$
}

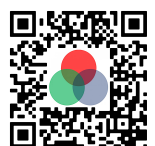

Use your smartphone to scan this QR code and download this article

${ }^{1}$ Institute of Microbiology, Faculty of Veterinary Sciences, University of Agriculture, Faisalabad, Pakistan (38000)

${ }^{2}$ Department of Pathology, Faculty of Veterinary Sciences, University of Agriculture, Faisalabad, Pakistan (38000)

${ }^{3}$ Department of Environmental Sciences, COMSATS University Islamabad Abbottabad Campus, Pakistan (38000)

${ }^{4}$ Institute of Pharmacy, Physiology and Pharmacology, University of Agriculture, Faisalabad, Pakistan (38000)

${ }^{5}$ Department of Microbiology, Government College University

Faisalabad, Pakistan (38000)

${ }^{6}$ Department of Wildlife and Fisheries, University of Agriculture, Faisalabad, Pakistan (38000)

\section{Correspondence}

Nishat Zafar, Institute of Microbiology, Faculty of Veterinary Sciences, University of Agriculture, Faisalabad, Pakistan (38000)

Email: nishat_zafar@yahoo.com

History

- Received: Sep 06, 2020

- Accepted: Oct 15, 2020

- Published: Nov 05, 2020

DOI : 10.15419/bmrat.v7i11.646

\section{Check for updates}

\section{Copyright}

(c) Biomedpress. This is an openaccess article distributed under the terms of the Creative Commons Attribution 4.0 International license.

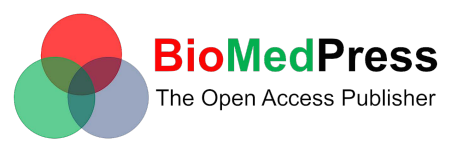

\begin{abstract}
Up to now, no vaccine has been developed for COVID-19 treatment. Although many scientists are working for the rapid development of a vaccine to control this pandemic, nonetheless, it will take time. If the vaccine will be developed soon, it will not be available to the entire world instantly since the mass production of the vaccine will take time. In this scenario, we will have to take alternative measures to control the COVID-19 pandemic. These alternative approaches include the stimulation of the immune system to fight against viral infections. Among the different approaches to strengthen the immune system, the use of probiotics is the best one. Probiotics can help the body to fight against COVID-19 directly and indirectly. In this review, we comprehensively discuss the use of probiotics for the prevention and control of COVID-19.
\end{abstract}

Key words: COVID-19, Probiotics, Immune stimulation

\section{INTRODUCTION}

In Wuhan, China, the World Health Organization (WHO) declared a vague type of pneumonia on the $31^{\text {st }}$ of December 2019 and it was identified as a public health importance of international concern ${ }^{1,2}$. In Central China, Wuhan is known as the most overcrowded city with approximately 11 million residents. Over 27 pneumonia cases of unknown cause were found in Wuhan city with clinical symptoms of cough, fever, dyspnea, and pulmonary infiltrates on tomography ${ }^{3,4}$. All patient cases were associated with the Huanan Seafood Wholesale Market, where sales of fish and other kinds of live animals, such as chicken birds, bats, snakes and squirrels, had taken place. The occurrence of cases of severe pneumonia with unknown etiology was thought to be the starting point of a potential epidemic ${ }^{5}$. Due to the massive movement of people during the Chinese Spring Festival, which potentially fueled the epidemic further, public transport was deferred in Wuhan city and ultimately in all other cities in the Hubei Province to minimize the transmission of infection ${ }^{6}$.

On 7th January 2020, the Chinese Center for Disease Control conducted a study to identify the etiology through swab samples from the throat. Subsequently, the etiological agent was identified and named as severe acute respiratory syndrome coronavirus 2 (SARS-CoV-2), and the World Health Organization named the infection as COVID-19 ${ }^{7}$. Initially, patients having SARS-CoV-2 infection presented slight symptoms including dry cough, fever, and sore throat. The majority of the cases presented severe clinical signs and symptoms such as organ malfunction, low blood pressure, lung edema, pneumonia, and Acute Respiratory Distress Syndrome $(\mathrm{ARDS})^{8}$. It is reported that $55.3 \%$ of male patients were infected with SARS-CoV-2 with the average age of 50-60 years. Particularly, the old age group required intensive care support due to multiple disease histories including cardiovascular, cerebrovascular, and respiratory disorders ${ }^{9}$.

\section{CORONAVIRUS HISTORY}

Coronaviruses are positive-sense RNA enveloped viruses and their diameter varies from 60 to $140 \mathrm{~nm}$. On the surface, they have spike projections which appear as crown-shaped under electron microscopy and, thus, the virus was named as coronavirus ${ }^{10}$. Coronavirus belongs to the subfamily Coronavirinae and the family Coronaviridae of the Nidovirales. Four types of genera have been included in the subfamily Coronavirinae such as Alphacoronavirus, Beta-coronavirus, Gamma-coronavirus, and Delta-coronavirus ${ }^{11}$.

In the past two years, two incidents of the epidemic have occurred in which beta coronavirus was transmitted from animals to humans with dreadful outcomes $^{12}$. In 2002-2003, the first incidence occurred in the Guangdong Province of China in which novel beta coronavirus was transmitted from bats to humans with the aid of intermediate hosts like palm civet cats ${ }^{13}$. This novel beta-coronavirus was known to cause severe acute respiratory syndrome which affected thousands of people in China and Hong Kong. 
In Saudi Arabia in 2012, middle east respiratory syndrome (MERS) coronavirus was identified from bat and dromedary camels as their intermediate host and it also affected hundreds of people at that time with a fatality rate of $34 \%{ }^{14}$. Currently, the world is dealing with another pandemic caused by the spread of coronavirus originating from bats and spreading in the human population which is named COVID-19 ${ }^{15}$. This review is about the recent and ongoing pandemic which started in China on $31^{\text {st }}$ December 2019. The review highlights the main source of viral infection, as well as its prevalence, analysis, pathogenesis, and ways to control the outbreak; moreover, the role of probiotics for the control of COVID-19 will be a predominant discussion.

\section{COVID-19 EPIDEMIOLOGY}

The WHO recognized that the COVID-19 outburst emerged from the meat of wild animals sold in the 'wet markets' of South China. Recently, it was reported that this disease was first identified in Wuhan China on $31^{s t}$ of December $2019^{12}$. This virus spread throughout China after just a few weeks of emergence. Then, it spread within a month to various other countries, including Germany, Italy, and the United States of America ${ }^{16}$.

The incidence curve can be roughly grouped into 3 phases: ${ }^{17}$

1. The first phase of the epidemic occurred by contact in the wholesale food market located in Wuhan and in December 2019, the first case of COVID-19 was reported. Approximately 6 patients were admitted to the hospital from the $18^{\text {th }}$ to $29^{\text {th }}$ December 2019, and one of these hospitalized patients died. Analysis reports showed that people in the initial phase were responsible for the transmission of infection by close contact ${ }^{18,19}$.

2. The second phase begun on $2^{\text {nd }}$ January 2020, apparently by the hasty spreading of COVID19 in the hospitals resulting from nosocomial infection and person-to-person transmission (close contact). On $2^{\text {nd }}$ January 2020, 42 people had been hospitalized and all patients had been confirmed for COVID-19 disease ${ }^{20,21}$. It was reported that most of the hospitalized patients had a disease history of hypertension, diabetes, and heart problems. In Beijing city and Guangdong Province, 19 confirmed cases were noticed which raise the epidemic curve and total cases elevated to 205. Temporarily, Wuhan city was completely locked and banned from any locomotion inside and outside the city. Ultimately, this duration of lockdown overlapped with the traditional movement of people (a form of homecoming) before the Chinese New Year and, consequently, over 5.3 million people had departed from Wuhan ${ }^{22,23}$. The epidemic rapidly spread outside China. On $13^{\text {th }}$ January 2020, the first case was reported in Thailand which occurred due to the person traveling from Wuhan to Thailand ${ }^{23,24}$. By $23^{\text {rd }}$ January 2020, 29 provinces and 6 countries had to combat COVID-19 and a total of 76,897 confirmed COVID-19 cases were reported on 20th February 2020, which included 2,946 deaths in mainland China, 73,839 in Thailand, 76 in Hong Kong, 12 in Macao, and 24 in Taiwan. Approximately there was a 20 -fold increase in the number of cases compared to the initial phase ${ }^{25,26}$.

3. The third phase of the epidemic commenced on the $26^{\text {th }}$ of January 2020, which was prominent due to the elevated number of cases. In Beijing, Shanghai, Jiangsu, and Shandong, on the $10^{\text {th }}$ of February 2020, epidemiological studies revealed that the elevated number of cases accounted for $65-85 \%$ of all confirmed cases. The numbers showed a 240 -fold increase (reported 9,972 confirmed cases) as of the $30^{\text {th }}$ of January $2020^{27,28}$. The WHO declared this outbreak as a public health emergency of international concern (PHEIC). On the $1^{\text {st }}$ February 2020, the first case of person-to-person transmission of COVID-19 was reported in the United States. The Center of Disease Control (CDC) in the US screened more than 35,000 travelers reaching United States airports. In this initial screening, 435 travelers were examined for COVID19 infection in 40 states across the United States of America. Just 16 peoples were found to be carriers and 419 were negative. Unluckily, on the $12^{\text {th }}$ of February 2020, 42 doctors, 1,789 paramedics staff, and 387 health care workers were infected throughout the world ${ }^{29,30}$.

On February $10^{t h}, 2020$, in China, the percentage of infected people were starting to decrease from $98.3 \%$ to $11 \%$, with the success being owed to the lock down of Wuhan. Contrary to this, the infected cases became elevated in other countries- from $0.67 \%$ to $91 \%$ in the similar period ${ }^{31,32}$. According to reports ${ }^{33,34}$, the worldwide prevalence of cases until May 2020 are shown in Table 1. The total of COVID-19 cases reported and deaths reported, according to the data 


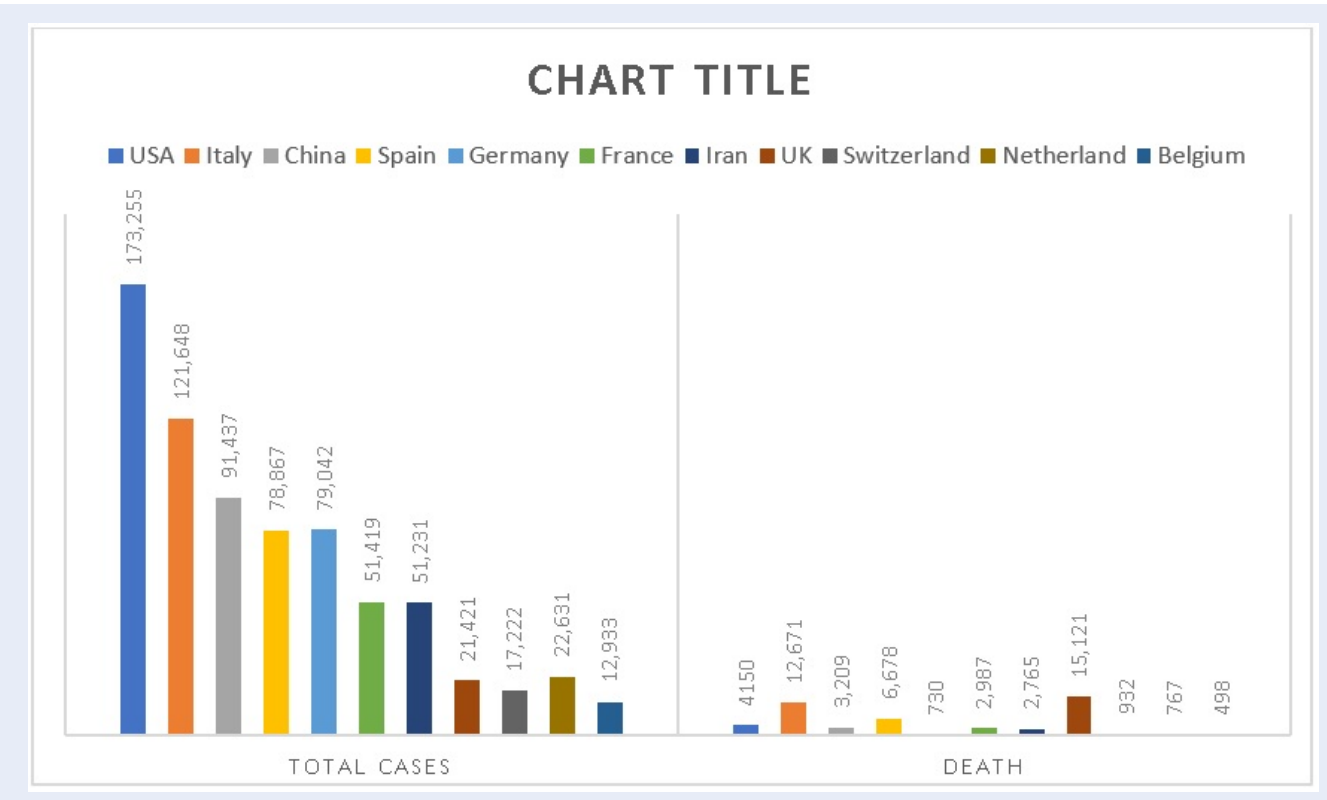

Figure 1: Total reported and death cases in different countries from $31^{s t}$ December to May $2020^{12}$. According this chart, the number of cases is high in the USA, Italy, and China, but the death rate is high in the Netherlands, UK, and Spain.

Table 1: Worldwide prevalence of confirmed cases of COVID-19 until May $2020^{11}$

\begin{tabular}{lccc}
\hline Date & China & Other countries & No. of Infected countries \\
1-March-20 & 310 & 1946 & 15 \\
12-March-20 & 5473 & 10,66 & 19 \\
28-March-20 & 15743 & 103,273 & 24 \\
1-April-20 & 78234 & 212,309 & 25 \\
14-April-20 & 31157 & 214,545 & 26 \\
22-April-20 & 76554 & 295,300 & 27 \\
30-April-20 & 69662 & 297,886 & 47 \\
4-May-20 & 70366 & 299,998 & 77 \\
10-May-20 & 70829 & 425,357 & 110 \\
16-May-20 & 798123 & 792,450 & 161 \\
22-May-20 & 790234 & 701,222 & 189 \\
26-May-20 & 820563 & 891,732 & 198 \\
30-May-20 & 83225 & 877,610 & 210 \\
\hline
\end{tabular}


analysis reports up to May 2020, are shown in Figure $1^{35,36}$.

Since $31^{\text {st }}$ December 2019 and as of $18^{\text {th }}$ October 2020, 39,774,852 cases of COVID-19 (in accordance with the applied case definitions and testing strategies in the affected countries) have been reported, including $1,110,902$ deaths.

Cases have been reported ${ }^{35,36}$ :

Africa: 1,638,567 cases; the five countries reporting most cases are South Africa $(702,131)$, Morocco $(170,911)$, Egypt $(105,297)$, Ethiopia $(88,434)$ and Nigeria $(61,307)$.

Asia: $12,349,067$ cases; the five countries reporting most cases are India $(7,494,551)$, Iran $(526,490)$, Iraq $(423,524)$, Bangladesh $(387,295)$ and Indonesia $(357,762)$.

America: $18,773,414$ cases; the five countries reporting most cases are United States $(8,106,752)$, Brazil $(5,224,362)$, Argentina $(979,106)$, Colombia $(952,371)$ and Peru $(865,549)$.

Europe: 6,976,052 cases; the five countries reporting most cases are Russia $(1,384,235)$, Spain $(936,560)$, France $(867,197)$, United Kingdom $(705,428)$ and Italy $(402,536)$.

Oceania: 37,056 cases; the five countries reporting most cases are Australia (27,383), French Polynesia $(3,797)$, Guam $(3,617)$, New Zealand $(1,530)$ and Papua New Guinea (581).

Other: 696 cases have been reported from an international conveyance in Japan.

Deaths have been reported ${ }^{35,36}$ :

Africa: 39,554 deaths; the five countries reporting most deaths are South Africa $(18,408)$, Egypt $(6,109)$, Morocco $(2,878)$, Algeria $(1,846)$ and Ethiopia (1,346).

Asia: 221,299 deaths; the five countries reporting most deaths are India $(114,031)$, Iran $(30,123)$, Indonesia $(12,431)$, Iraq $(10,198)$ and Turkey $(9,224)$.

America: 608,716 deaths; the five countries reporting most deaths are United States $(219,289)$, Brazil $(153,675)$, Mexico $(86,059)$, Peru $(33,702)$ and Colombia $(28,803)$.

Europe: 240,306 deaths; the five countries reporting most deaths are United Kingdom $(43,579)$, Italy $(36,474)$, Spain $(33,775)$, France $(33,392)$ and Russia $(24,002)$.

Oceania: 1,020 deaths; the five countries reporting most deaths are Australia (904), Guam (66), New Zealand (25), French Polynesia (14) and Papua New Guinea (7).

Other: 7 deaths have been reported from an international conveyance in Japan.
The primary assessment of COVID-19 spreading revealed that the basic reproductive number $\left(\mathrm{R}_{0}\right)$ of COVID-19 was evaluated to be 1.4-3.9, the $\mathrm{R}_{o}$ of SARS-CoV was 2.3-3.7, and the $\mathrm{R}_{o}$ of MERS-CoV was 0.50-0.92. It should be noted that $\mathrm{R}_{o}$ evaluation may fluctuate upon various social behavioral and environmental factors, and thus must be deduced with care $^{37,38}$.

\section{KEY FEATURES AND ENTRY MECHANISMS OF HUMAN CORONAVIRUSES}

Coronavirus consists of particular genes in the ORF1 downstream region that encodes for proteins involved in the production of nucleocapsid, spikes, and replication of virus. Spikes are made up of glycoproteins and are present on the outer surface of coronavirus ${ }^{39,40}$. These spikes help in the attachment and penetration of the virus in the host cell (Figure 2). Among viruses, the receptor-binding domain (RBD) is loosely attached; hence, due to this RBD, coronavirus may infect more than one host. In the case of COVID-19, aminopeptidase and carbohydrates are used as the primary receptor for penetration of virus into the human host, whereas SARS-CoV and MERSCoV recognize exopeptidase ${ }^{41,42}$. The mechanism of virus penetration depends upon cellular proteases, such as human airway trypsin-like proteases (HAT) and transmembrane protease serine 2 (TMPS2), as well as cathepsins that split the spike proteins and create further penetration changes. MERS-CoV requires dipeptidyl peptidase 4 (DPP4), whereas SARS-CoV employs angiotensin-converting enzyme 2 (ACE2) as the primary receptor ${ }^{43}$.

SARS-CoV-2 has a typical structure with spikes (protein) and also expresses other polyproteins, nucleoproteins, and membrane proteins (like RNA polymerase, 3- chymotrypsin-like protease, papain-like protease, helicase, and glycoproteins $)^{42}$. The spike protein is comprised of a $3 \mathrm{D}$ configuration in the $\mathrm{RBD}$ region to sustain the van der Waals forces. In SAS-CoV-2, the 394-glutamine residue in the RBD region is recognized by the critical lysine 31 residue on the human ACE2 receptor ${ }^{44,45}$. The complete pathogenicity mechanism of SARS-CoV-2, from attachment to replication, is described in Figure 3.

\section{GENOMIC VARIATIONS OF SARS-COV-2}

The SARS-CoV-2 genome homology has identified over $80 \%$ of the SARS-CoV. Four structural genes encode structural proteins which entail Spike (S), Membrane $(\mathrm{M})$, and nucleocapsid $(\mathrm{N})$ proteins. In SARSCoV-2, the orflab gene is known as the bulkiest gene, 


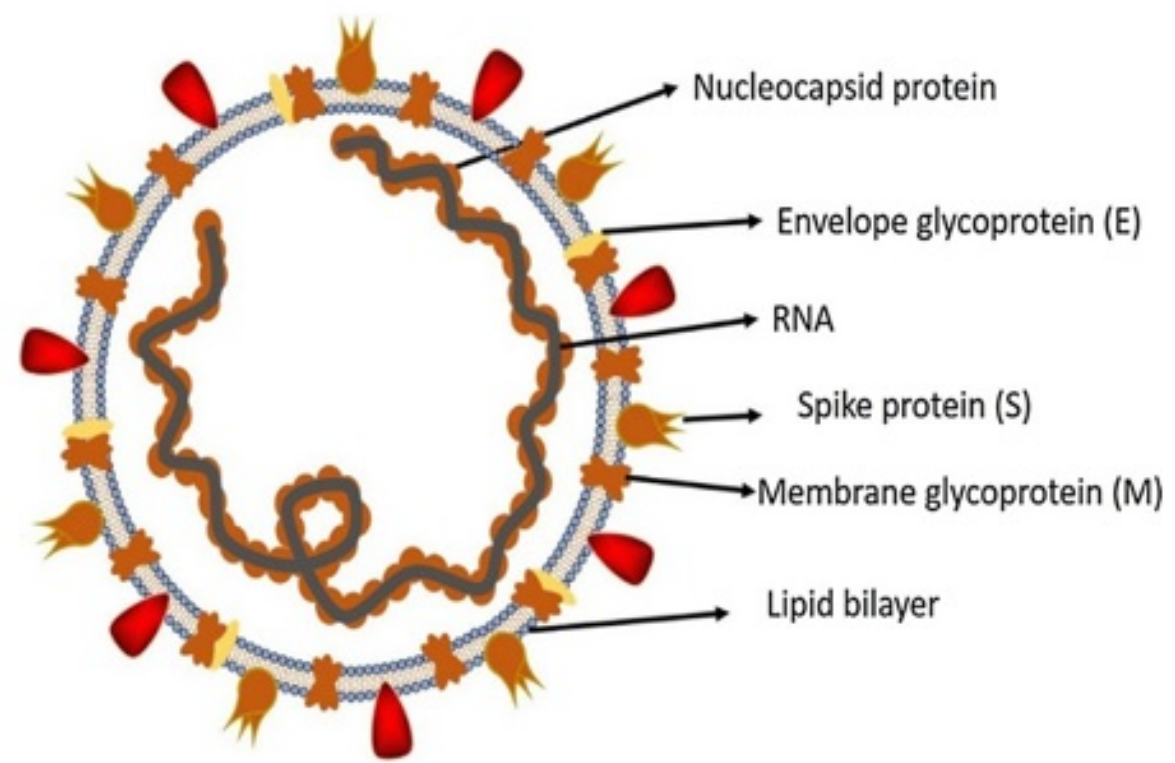

Figure 2: Structure of respiratory syndrome causing human coronavirus. This structure indicates that this is an RNA virus, the spikes protein having lipid bilayer along with enveloping glycoprotein and membrane glycoprotein.

which encodes pplab and 15 non-structural proteins $(\mathrm{nsp})^{3}$. The orfla gene encodes ppla proteins which are also comprised of $10 \mathrm{nsp}$. Prior studies have indicated a noticeable difference in SARS-CoV and SARS$\mathrm{CoV}-2$, which includes the absence of $8 \mathrm{a}$ protein and variation in the amino acid numbers in $8 \mathrm{~b}$ and $3 \mathrm{c}$ protein of SARS-CoV-2, as shown in Figure 4. It is also noted that spike proteins of coronavirus isolated from Wuhan is modified through homologous recombination $^{1,2}$. Additionally, it has been noted that the SARSCoV-2 also uses the same ACE2 receptor for the attachment of the virus to the host cell, which was previously used by the SARS-CoV. A single mutation in the spike proteins of SARS-CoV-2 may have considerably increased its attachment affinity for ACE2 $2^{4,5}$.

\section{SIGN AND SYMPTOMS OF COVID-19}

The sign and symptoms of COVID-19 infection have seemed to appear after 5-9 days, which is the incubation period. The duration from the appearance of symptoms to death has ranged from 7 to 42 days. This duration highly depends on the patient's age and the condition of the patient's immunity. This period is shorter in those patients who are less than 60 years old ${ }^{6,7}$. Primarily, the person suffers from a runny nose and sore throat for 2-3 days, followed by an infrequent degree of fever while further symptoms have also included headache, hemoptysis, diarrhea, sputum production, lymphopenia and dyspnea ${ }^{8}$. Tomography of the infected patients has revealed pneumonia, acute respiratory syndrome, acute cardiac infection, and RNAemia, which have led to mortality. In some patients, multiple pulmonary nodules were detected in the subpleural area of both lungs which stimulated both localized and systemic immune responses that led to increased infection ${ }^{9}$. Unfortunately, treatment with interferon intake showed no promising effect and, in fact, worsened the situation of the patients by progressing pulmonary opacities, as shown in Figure 5 .

It is noteworthy that there are resemblances in the signs and symptoms of COVID-19 and betacoronavirus; these signs/symptoms include dry cough, fever, dyspnea, and hazy bilateral opacity on chest tomography ${ }^{10}$. Furthermore, some clinical features have been observed in COVID-19 infection, such as upper respiratory tract infections, rhinorrhea, sneezing, and sore throat ${ }^{10}$. However, chest tomography of the patients has shown infiltrates in the upper lobe of the lungs that are linked with increasing dyspnea with hypoxemia. Significantly, COVID-19 infected patients have developed gastrointestinal tract infections such as diarrhea, while fewer cases of SARS-CoV and MERS-CoV had GI infections ${ }^{12}$. 


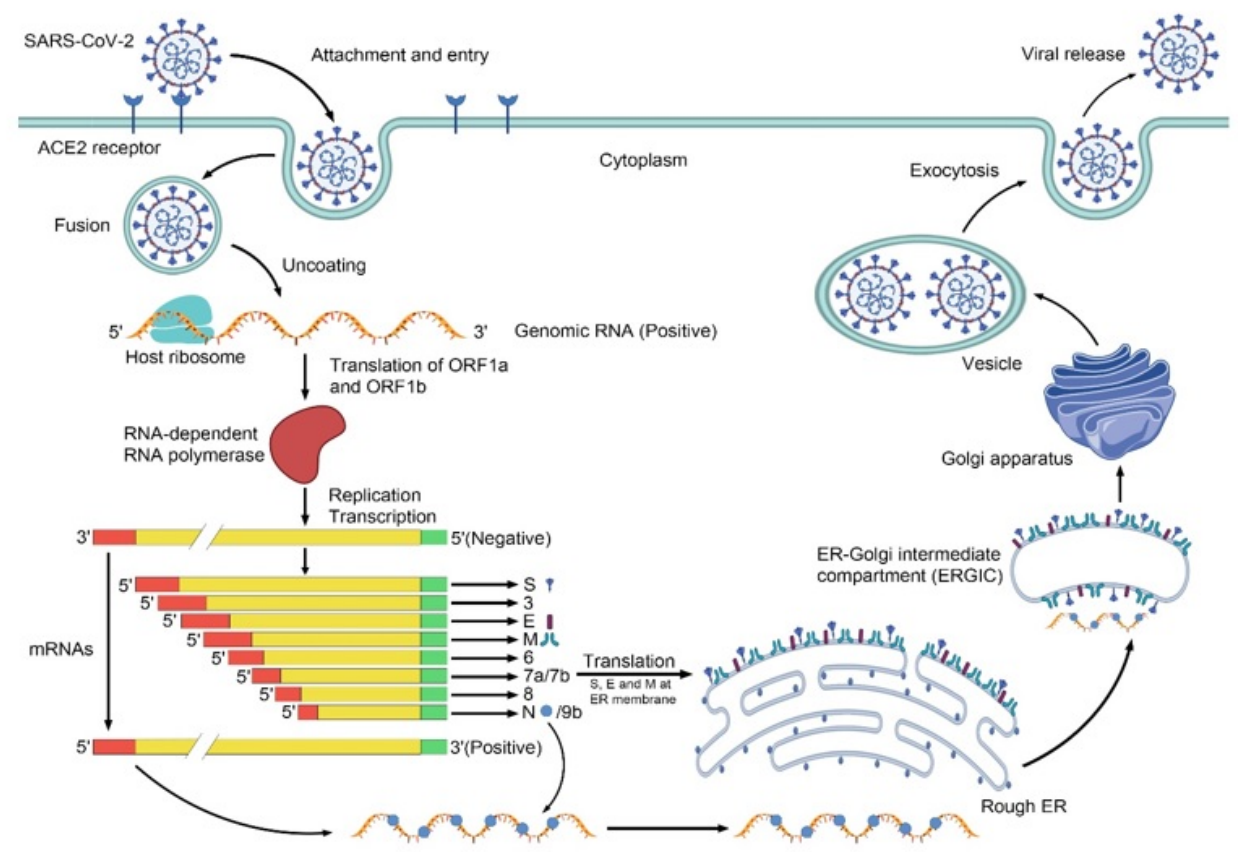

Figure 3: The life cycle of SARS-CoV-2 in the host cell. The life cycle begins when S protein attaches to the ACE2 cellular receptor. After attachment, the conformational changes in the $\mathrm{S}$ protein stimulates the fusion of the virus to envelop with the cell membrane through the endosomal pathway. Then the virus liberates its RNA into the cell, and translation begins. Viral replicase polyproteins pp1a and $1 \mathrm{ab}$ are expressed from RNA, which are then splits into small products by viral proteinases. A series of subgenomic mRNAs are formed by discontinuous transcription through RNA polymerase and are translated into particular viral proteins. In ER and Golgi apparatus, viral RNA and viral proteins are successively organized into virus particles and Lastly, virus particles in the vesicles fused with the cell membrane of the host cell and then released through the process of exocytosis. According to Li et al., 2020, the virus-cell, when released from the host lung cell, enters into the peripheral blood circulation and stimulates viremia ${ }^{26}$.

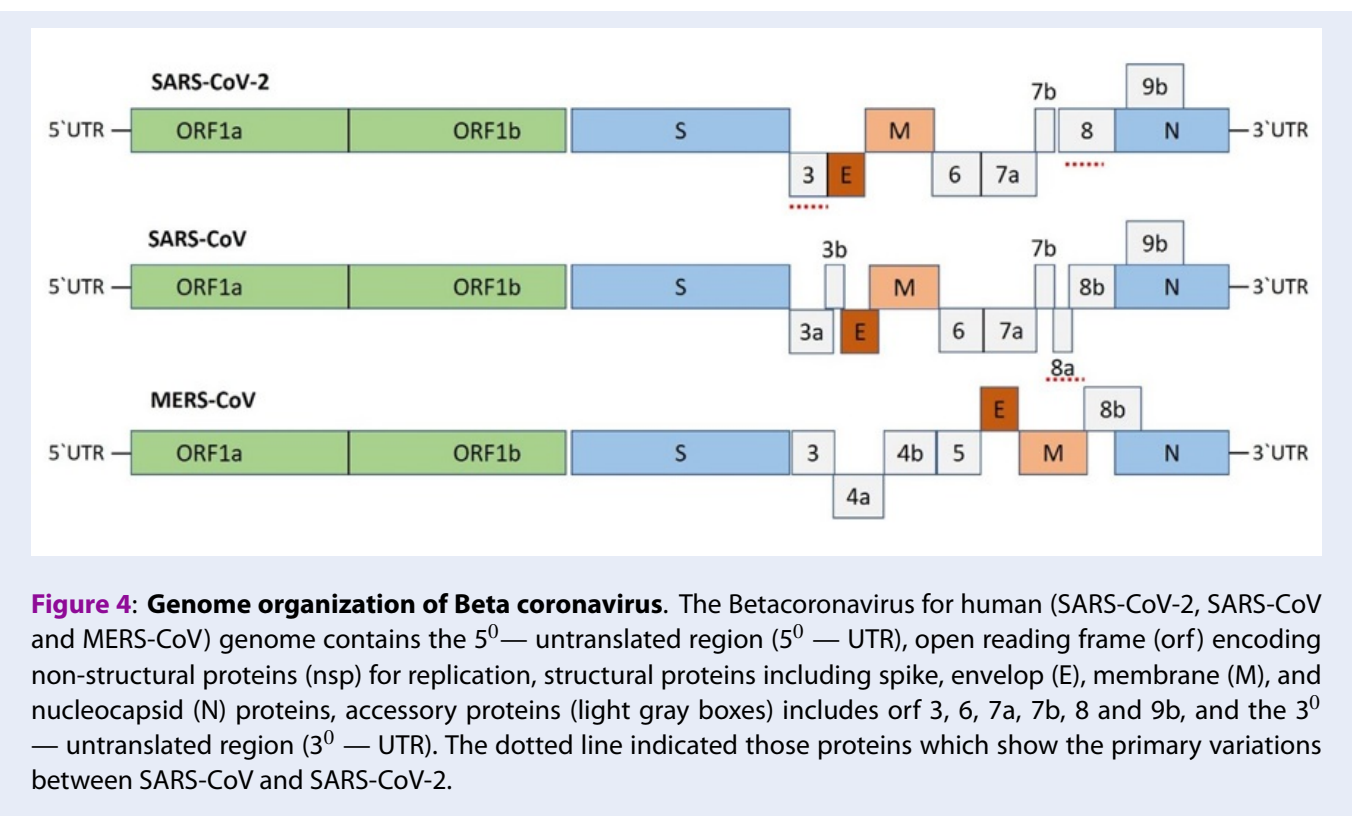


Respiratory Disorders

Sneezing

Sore Throat

Pneumonia

Ground-glass Opacities

Acute Respiratory Distress Syndrome

RNAaemia
Systemic Disorders

Fever

Dry Cough

Fatigue

Sputum Production

Headache

Diarrhoea

General Body Aches

Hypoxemia

Dyspnoea

Heamoptysis

Acute Cardiac Injury

Lymphopenia

Figure 5: Clinical signs developed in COVID-19 infection. Most the clinical signs of COVID-19 appear in the respiratory system.

Thus, it is significant to develop methods for the identification of different routes of transmission like fecal and urine samples and immediate examinations in order to develop strategies to minimize viral transmission and to develop medicines to minimize the risk of disease.

\section{ANALYSIS OF COVID-19 INFECTION}

The key evaluation of the clinical signs and symptoms of COVID-19 infection was declared in a presentation in Wuhan city. However, despite the continually prolonged and abstruse situation of the pandemic, the Chinese and American Centers for Disease Control (CDC) introduced as prevention various surveys and reagents which were generated for aiding the recognition of several infections in the clinical samples ${ }^{13}$. Majumder and Mandl (2020) concluded that several investigators used real-time PCR methods to test for COVID-19. The RT-PCR mixture contains an open reading frame (Orf), envelope $(\mathrm{E})$, nucleocapsid $(\mathrm{N})$, and RNA-subordinate RNA polymerase (RdRp) ${ }^{14}$. On the $4^{\text {th }}$ of February 2020 a significant step was undertaken by the United States Food and Drug Admiration (FDA) when the agency provided the authorization of the US CDC's COVID-19 detection kit (via PCR methodology) and also invested in the CDC licensed research facilities to perform the detection testing. Currently, 115 CDC research labs are operating in the US, with approximately 191 licensed labs worldwide $^{15}$. Within 2-14 days of exposure, symptoms of fever, cough, and breathing problems occur, followed by continuous cardiac pain and discomfort, experience of misperception, and bluish lips or face; all these are believed to be signs of COVID-19 ${ }^{16}$. Despite the fact that there is no logical history of appearance of symptoms, a COVID-19 case should be considered as having 3 clinical symptoms, such as fever, cough, and breathing problems. In the description of the $5^{\text {th }}$ clinical sign, computed tomography (CT) of chest scan can recognize viral pneumonia, which is regarded as a confirmation of COVID-19 infection ${ }^{28}$. It is interesting to note that WHO did not allow the chest computed tomography without the RT-PCR test 
until February $17^{\text {th }}, 2020$. Furthermore, novel coronavirus pneumonia diagnosis and treatment program of 2019 has expelled out the clinical analysis for the detection of COVID-19. As showed from the clinical symptoms, confirmed patients are grouped into mellow, mild, severe, and uncomplicated cases ${ }^{17}$.

\section{IS THERE ANY VACCINE AVAILABLE FOR COVID-19 TILL TODAY?}

Researchers worldwide are working around the clock to find a vaccine against SARS-CoV-2, the virus causing COVID-19 pandemic. The herculean effort means that a fast-tracked vaccine could come to market anywhere from the end of 2020 to the middle of $2021^{46}$. To date just two corona virus vaccines has approved sputnik V-formally known as Gam COVIDVav and developed by Gamaleya research institute Moscow. Experts have raised considerable concerns about the vaccine safety and efficacy given it has not entered the phase 3 clinical trials. A second vaccine in Russia EpiVacCorona has also been granted regulatory approval, also without entering phase 3 clinical trials $^{46}$.

\section{STRATEGIES TO CONTROL COVID-19}

There are several problems in evading the infection caused by COVID-19 in various areas, such as clinically sensitive cases or atypical introductions. The CDC has proposed that the medical staff should use personal protective equipment (PPE), and follow the standard protocols of safety measures of airborne pathogens, including covering the eye ${ }^{18}$. It has been suggested that medical service providers should wear protective attire, gloves, N95 mask, and air removal respirators ${ }^{19}$. The CDC proposed the manifestation of airborne infection detention rooms that should be reserved for COVID-19 patients. Furthermore, the CDC recommends the implementation of environmental pollution controls, by assuring proper techniques of ecological cleaning and purification methods. Designing control usages, such as physical limitations, used curtains between two patients in shared spaces, air filters for inappropriate air route, and quarantining, could reduce the occurrence of COVID19 cases $^{8}$. Safety and health authorities had made policies to help the forest all the onset and spread of COVID-19, such as hand washing for at least $20 \mathrm{sec}-$ onds after every half an hour and use of liquor sanitizes having a minimum of $65 \%$ liquor. Prevention of touching nose, eyes, face with grubby hands, as well as avoidance of close interaction with other persons, are also critical ${ }^{20}$.
Antibodies from COVID-infected persons can be an ultimate solution in preventing and eliminating COVID-19. Still, no booster of the immune system against SARS-CoV-2 is available. Vaccines are now being developed for immunization. The National Institutes of Health (NIH) is on phase 1 to develop a mRNA antibody; it is currently in its initial stages (March 2020). Due to the deficiency of an appropriate remedy, an ideal action to control the SARS-CoV-2 disease is to reduce the risk factor of this outbreak ${ }^{21}$. Likewise, safety measures should be important in the prevention of COVID-19; these include improvement of health hygiene, use of medical masks, proper rest, social separation, and staying at home in well-aerated rooms. Until the development of vaccines, this pandemic can be controlled by improving the immune status of the cases in different ways, such as the use of probiotics.

\section{ROLE OF PROBIOTICS TO CONTROL COVID-19}

Despite policies such as safety measures, isolation, and social separation to limit COVID-19 infection, and despite the fact these policies have been quickly shared globally to aid in the medical management of COVID-19, there is still much threat and concern about infection. Even though the discovery of medical interventions for COVID is rampant and ongoing, such treatments like vaccines will not be available until possibly late in the coming year. Thus, more prophylactic approaches are necessary ${ }^{22}$. A variety of symptoms have been identified which are caused by COVID-19, including flu-like systems, pneumonia, severe respiratory infection, and failure of body organs. Therefore, in the spread of SARS-CoV-2, air droplets are the main source and the gastrointestinal tract may also be involved in the pathogenesis of coronavirus. RNA of SARS-CoV-2 has also been found in the patients' gut and fecal samples, and in the sewage pipelines. SARS-CoV-2 can infect intestinal absorptive cells, thus acting as a carrier for COVID$19^{23}$. Certainly, from China, large clinical data have revealed that gut infection is common in coronavirus and contributes to the severity of disease. Probiotics are vital microorganisms that when consumed at a sufficient dose, can confer a beneficial effect in the host. Medical data have shown that particular strains of probiotics facilitate the prevention of viral and bacterial infections, such as sepsis, gastroenteritis, and respiratory tract syndrome ${ }^{24}$. The purpose of discussing probiotics in the prevention of bacterial and viral infections is founded in science and medical data, although not directly on the etiological agent of this outbreak. 


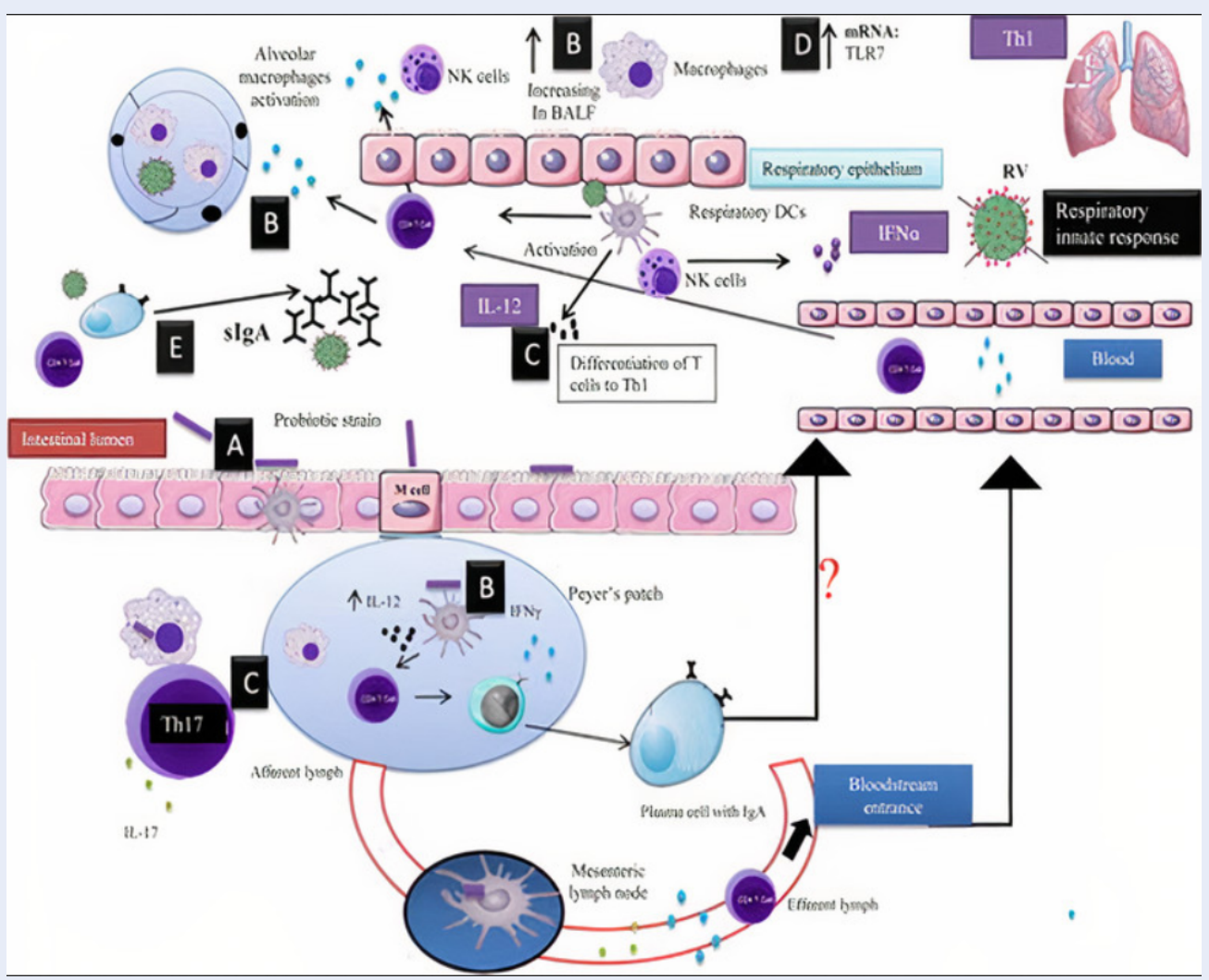

Figure 6: This figure illustrates the antiviral process of several strains of probiotic used in opposition to respiratory viral (RVs) infection. Viruses inhibited via probiotics and can aid the immunity to protect it from RVs. Initially, RVs attach to the epithelium layer of the respiratory tract, then immediately an innate immune system activated through the production of IFN signals and some pro-inflammatory cytokines. After the secretion of cytokines, Macrophages and Natural Killer cells will be engaged to engulf and inhibit virus molecule and infected cells. (A) Probiotic cooperate with the epithelium layer of the gut and are detected by the intestinal dendritic cells (IDCs); this cooperation effects the development of IFN $\gamma$ and IL-12 via IDCs, which helps to control the immune responses of Respiratory tract and gut. (B) the secretion of two pro-inflammatory cytokines (IFN $\gamma$ and IL-12) have two functions: these two cytokines can disseminate in the blood circulation to reach the epithelium layer of respiratory tract. Consequently, it can aid the alveolar macrophages and natural killer cells to remove RVs. (C) Due to the settlement of strains of probiotics, two cytokines released in the gut biota. Due to this settlement, immune system produces a particular Th1/Th 17 response; $\mathrm{CD}^{+}$and $\mathrm{CD} 8^{+}$number rises and become more efficient. Moreover, $\mathrm{CD}^{+}$will release IL-17, which boost up the innate immune system. (D) several strains of probiotic, through production of two cytokines, can enhance the over expression of genes related to innate immune system, like TLR7, even in the lungs. The TLR7 over expression stimulate the innate immune system. (E) probiotics can aid the differentiation of B lymphocytes and turn into plasma cells, which can release particular slgA. Several probiotic strains can influence the production of cytokines and can enhance the B lymphocytes differentiation to plasma cells in tissues of lungs ${ }^{37}$.

\section{EVIDENCE THAT SUPPORTS THAT PROBIOTICS CAN FIGHT AGAINST COVID-19}

Probiotics can control drug-associated diarrhea and gastrointestinal tract infection, and control other sites of infections like respiratory tract infections and sepsis. For evidence-based medicines, the gold standard would be the meta-analysis ${ }^{26}$. In one investigation on approximately 9,000 newborns counted in randomized controlled trials, the mother's intake of probiotics through the gastrointestinal tract could decrease necrotizing enterocolitis, nosocomial sepsis, and mortality risk ${ }^{25}$. A well-organized randomized controlled trial in India consisting of more than 5,000 infants treated with lactobacillus plantarum strain associated with prebiotics showed a declining level of sepsis and lower respiratory tract infections ${ }^{27}$. Viruses are the main factor causing upper respiratory tract infections. In the prevention of upper respira- 
tory tract infections, the beneficial effect of probiotics has been confirmed. Multiple studies of 13 randomized controlled trials have been conducted which contains 4,230 youngsters and kids who were given probiotics $^{28}$; there was a 2 -fold decrease in risk of lower and upper respiratory tract infections and a lower but noteworthy decrease in the severity of disease in the carrier patients. Moreover, there was a randomized, double-blinded placebo-controlled study with 523 youngsters who were given lactobacillus gasseri PA 16/8, Bifidobacterium longum SP 07/3, and Bifidobacterium bifidum MF 20/5, with some minerals and vitamins. The results showed lower flu periods and also a reduction in fever days ${ }^{29}$. A randomized controlled trial containing 93 newborns were given galacto-oligosaccharides and polydextrose prebiotic combination (1:1) and Lactobacillus rhamnosus GG in 3 to 60 days. Treatment reduced by 2 - to 3 -fold the occurrence of respiratory tract viral infections as compared to the placebo-control. The occurrence of rhinovirus-related events which include $85 \%$ of all respiratory tract infection cases in this study was also highly decreased with the consumption of prebiotics and probiotics. Lactobacillus brevis has also demonstrated promising results in a study of 1,692 school kids and strongly reduced the occurrence of influenza respiratory tract infections ${ }^{30}$. In studies, the outbreak has distressed the youngsters moreso than kids, but Bifidobacterium longum has been documented in a randomized controlled trial of 28 adults and has also shown promising results. Moreover, many probiotics are being selected from lactic acid bacteria that are commonly found in the upper respiratory tract of healthy persons, and most of the probiotic strains are listed in the prevention of persistent otitis me$\mathrm{dia}^{31}$. Thus, it can be concluded that probiotics have a valid contribution in slowing down the incidents of coronavirus outbreak. Apart from use in viral infections, probiotics can also help in reducing bacterial infections like lower respiratory tract infections in adults. Multiple experimental data have been obtained from a randomized controlled trial containing 2,000 infected patients of ventilator-related pneumonia. In this study, the results from more than 1,800 adults showed recovery and reduction of incidents ${ }^{32}$. However, evidence of lower quality and contradictory results in various trials warrants further investigations with well-organized randomized and controlled design. It must be noted that not all probiotics are involved in decreasing the risk of respiratory tract infections, even the probiotics with gastrointestinal benefits. For example, Bifidobacterium animalis and Lactobacillus rhamnosus might contribute to intestinal aid but do not decrease the virus number in the nasophar$\mathrm{ynx}^{33}$. Examples of probiotic products that could be beneficial in all aspects depend on their accessibility in a given country, as shown in Table 2 .

\section{MECHANISM OF ACTION OF PROBIOTICS TO PREVENT COVID-19}

Studies that discuss success of probiotics in clinical trials have indicated parameters such as improvement of the epithelial barrier of intestines, competition with disease-causing agents for nutrients, attachment on the epithelium wall of intestines, production of antipathogen elements, and enhancement of the immune system of the host ${ }^{34}$. A randomized controlled study design of 63 newborns who received enteral nutrition along with Bifidobacterium bifidum and Streptococcus thermophilus showed a decline in diarrheal incidents and reduction of rotavirus shedding, as demonstrated by results obtained from the meta-analysis. These findings indicate an interruption in the entry of the virus into the cell and inhibition of viral replication in the host intestine ${ }^{35}$. Therefore, this system may contribute to the reduction of coronavirus invasion through the gastrointestinal tract because probiotics are not taken in through the respiratory tract.

Consequently, at this site, direct prevention of viruses might not be possible. It is also reported that the microbiota is also found in the lungs; gut-lung association has been discussed whereby microbe-to-microbe and host-to-microbe immune collaborations might stimulate the progression of respiratory infections. Influenza-type infections are related to the discrepancy of microbial groups of the gastrointestinal and respiratory tracts ${ }^{36}$. This dysbacteriosis might change the functions of the immune system and prompt secondary bacterial infection. As studies from China have shown, COVID-19 may be accompanying intestinal dysbacteriosis, thereby causing severe infection; restoration of gut homeostasis may be helped through probiotic strains. It is reasonable that probiotic strains, when orally administered, could stimulate gut-lung association and some strains can migrate from the gut to other nearer sites, like breast, to medicate mastitis ${ }^{4}$. The microbiota of the gut has a significant effect on the host immune response, systemically, and on immune reactions at nearby mucosal sites, such as lung. Consumption of particular bifidobacterial and lactobacilli strains can have a positive effect on the clearance of influenza virus from the respiratory tract.

Certain strains of probiotic have enhanced interferon type I levels, elevating the number and function of 
Table 2: Probiotics with reports in human studies that may have contributed to decreasing the load of the COVID-19 outbreak

\begin{tabular}{|c|c|c|c|}
\hline Probiotics & Function of probiotics & $\begin{array}{l}\text { Administration dura- } \\
\text { tion }\end{array}$ & References \\
\hline $\begin{array}{l}\text { Lactobacillus casei DN-114 001; DanAc- } \\
\text { tive/Actimel Fermented drink, Danone }\end{array}$ & $\begin{array}{l}\text { Decrease occurrence and extent } \\
\text { of RTIs }\end{array}$ & $\begin{array}{l}\text { daily used in the pan- } \\
\text { demic duration }\end{array}$ & 45 \\
\hline $\begin{array}{l}\text { Lactobacillus gasseri PA } 16 / 8 \text {, Bifidobac- } \\
\text { terium longum SP } 07 / 3 \text {, and B. bifidum } \\
\text { MF 20/5; Tribion harmonis, Merck }\end{array}$ & $\begin{array}{l}\text { reduced extent and acuteness of } \\
\text { flu-type infection }\end{array}$ & $\begin{array}{l}\text { daily used in the pan- } \\
\text { demic duration }\end{array}$ & 3 \\
\hline $\begin{array}{l}\text { Lactobacillus rhamnosus GG; Culturelle } \\
\text { or other brand names }\end{array}$ & $\begin{array}{l}\text { For healthy digestion and gut } \\
\text { barrier strength, and anticipa- } \\
\text { tion of viral RTI. }\end{array}$ & $\begin{array}{l}\text { daily used one capsule in } \\
\text { the pandemic duration }\end{array}$ & 4 \\
\hline Lactobacillus plantarum DR7; Malaysia & $\begin{array}{l}\text { immune stimulation lowering } \\
\text { the upper RTI, }\end{array}$ & $\begin{array}{l}\text { daily used } 2 \mathrm{~g} \text { sachet in the } \\
\text { pandemic duration }\end{array}$ & 9 \\
\hline $\begin{array}{l}\text { Bifidobacterium breve Yakult, and Lac- } \\
\text { tobacillus casei Shirota; available as fer- } \\
\text { mented drinks }\end{array}$ & $\begin{array}{l}\text { reduce the prevalence of } \\
\text { ventilator-associated pneumo- } \\
\text { nia }\end{array}$ & $\begin{array}{l}\text { daily used in the pan- } \\
\text { demic duration }\end{array}$ & 35 \\
\hline $\begin{array}{l}\text { Bifidobacterium longum BB536; Mori- } \\
\text { naga, and sold in many formulations }\end{array}$ & $\begin{array}{l}\text { stimulate innate immune re- } \\
\text { sponse and, protects from in- } \\
\text { fluenza, }\end{array}$ & $\begin{array}{l}\text { daily used in the pan- } \\
\text { demic duration }\end{array}$ & 36 \\
\hline $\begin{array}{l}\text { Pediococcus pentosaceus } 5-33: 3 \text {, Leu- } \\
\text { conostoc mesenteroides } 32-77: 1, \text { L. para- } \\
\text { casei ssp. paracasei } 19, \text { L. plantarum } \\
2,362 \text { plus inulin, oat bran, pectin, and } \\
\text { resistant starch; Medipharm, Sweden }\end{array}$ & $\begin{array}{l}\text { To decrease the SIRS infection } \\
\text { rate, sepsis, duration of stay in } \\
\text { the hospitals especially on ven- } \\
\text { tilators, and rate of mortality }\end{array}$ & For COVID-19 patients & 36 \\
\hline \multicolumn{4}{|c|}{ A probiotics list accessible in Canada for several health problems: www.probioticchart.ca } \\
\hline
\end{tabular}

antigen-presenting cells, natural killer cells and $\mathrm{T}$ cells, as well as increasing the level of particular antibodies at the systemic and mucosal sites ${ }^{47}$. There is also proof that strains of probiotic can amend the stability among pro-inflammatory and immunoregulatory cytokines that permit the clearance of viruses. This could be mostly appropriate to avert the acute respiratory distress syndrome, a major impediment of COVID-19. A randomized controlled design includes teenagers who exhibit suppression of plasma pro-inflammatory cytokines, such as IFN- $\gamma$ and TNF$\alpha$, with the use of Lactobacillus DR7. Another trial of young adults showed improvement in antiinflammatory cytokines, like IL-4 and IL-10, and reduction in the peroxidation of plasma cells and oxidative stress levels ${ }^{37}$. Certain storms of cytokines might develop in patients with COVID-19, and this modulation type might prove to be very significant. The method in which strains of probiotic are orally consumed would contribute to the emergence of the im- mune response from the intestines, a crucial point of the host defenses. Therefore, strains of probiotics are known to improve the firmness of tight junctions; for instance, they could act as fuel for colonocytes which could tentatively reduce the invasion of SARS-CoV-2 by increasing the level of butyrate. Probiotic strains have also been demonstrated to exert anti-viral activity, as shown in experimental and medical studies ${ }^{38}$. However, none of these mechanisms and effects have been verified on SARS-CoV-2. This approach should not be refused, particularly when probiotic strains have been positively tested against other strains of coronavirus. Moreover, patients are also currently affected from secondary bacterial infections. A prior study showed that mice with pulmonary infection due to Pseudomonas aeruginosa and Staphylococcus aureus, when orally administered with probiotic strains of Lactobacillus acidophilus, demonstrated a decrease in the bacterial burden from the lungs and a reduction in the chances of lung impairment and systemic 
infection $^{39}$.

\section{SAFETY OF PROBIOTICS}

Probiotics are usually harmless even in the most susceptible communities and hospital settings. Some cases with bacteremia and fungemia related to probiotics have arisen mostly in immunocompromised persons, due to the absence of appropriate quality control; however, these have occurred in rare situations ${ }^{41}$. Most of the time, the probiotics are harmless, but it depends upon the dose of probiotics. If we use the proper dose of probiotic, then we can get the maximum results to control any infection, here, in this case, to prevent the viral infection. But if the dose of the probiotics is high, then it may cause some complications ${ }^{42}$. Furthermore, in a randomized controlled study of 72 critical patients consisting of various trauma parents and instinctively ventilated persons, the administration of Pediococcus pentosaceus, Leucnostoc mesenteroides, Lactobacillus paracasei, Lactobacillus plantarum, insulin, oat bran, pectin, and starch ensued a decrease in the rate of inflammation, systemic infection response disease, sepsis, and duration of stay in hospitals, especially on ventilators, as well as decrease in mortality rate ${ }^{40}$.

\section{DISCUSSION}

The emergence of COVID-19 began from the Wuhan Seafood Marketplace in China. Bats, snakes, palm civets, raccoon and hounds were sold in this market, and this was the source from where COVID19 rapidly invaded and spread to 110 nations of the world. The zoonotic source of SARS-CoV-2 has not been avowed, although sequence-based investigation has mentioned that bats are the chief source of SARSCoV-2, while the intermediary host is yet to be elucidated. Based on investigations of spike glycoproteins and DNA recombination, SARS-CoV has been classified into CoVZXC21 and CoVZC45 ${ }^{43}$. The quick genome sequence and open access information, along with modern vaccine development technology, has probably given us more information regarding therapeutic strategies against COVID-19 ${ }^{48}$. Therapy is generally based on the signs and symptoms of carrier patients, although strategies of vaccination and antiviral drugs are in progress. Presently, there are no convincing antibodies and specific antiviral therapies against COVID-19. Hereafter, we have to depend only on safety and control preventive measures that restrict the risk factors associated with the transmission of viral infection ${ }^{44}$. The outcomes of the test performed in the laboratories studying SARS-CoV-2 are important and assuring.

Meanwhile, therapies like Remdesivir and Chloroquine are intensely persuasive in the prevention of viral infections. According to pre-clinical trials, the $S$ protein is known as the main virus-producing antigen for immunization against COVID-19 ${ }^{45}$. However, studies which investigation prevention, medications, and strategies to control the infections caused by COVID-19 are in progress. The stated clinical data on several therapeutic strategies for COVID-19 are still incomplete. Additional research studies should be organized regarding the trials of SARS-CoV-2 in laboratory animal models, for examining their replication, transmission, and pathogenesis. Many virologists are working for the development of a vaccine to control the COVID-19. Some vaccines are in the final trial but will take time. Until the development of a vaccine, we will have to improve the immune system of the patients and use other alternative measures, such as use of probiotics, to control this pandemic.

\section{CONCLUSION}

This review article emphasizes the present situation of the COVID-19 outbreak and the role of probiotics as an immune booster to control this epidemic. Throughout this period, various studies have been conducted to understand the reason for transmission of COVID-19, its causes, signs and symptoms, and prevention and control strategies. More laboratory trials should be performed to understand the immune pathogenesis of COVID-19 and to aid in the development of novel therapeutic agents, like antiviral drugs and vaccines, to restrict the infection cycle of COVID-19. Furthermore, the government authorities should take steps to create awareness among the people through social networks at the district, national, and international levels to control the spread of COVID-19 infection. More studies are needed to support this idea that probiotics can play an important role in the prevention of this disease.

\section{ABBREVIATIONS}

ARDS: Acute Respiratory Distress Syndrome

ACE2: Angiotensin-converting enzyme 2

DPP4: Dipeptidyl peptidase 4

E: Envelope

FDA: Food and Drug Admiration

HAT: Human airway trypsin-like proteases

MERS: Middle east respiratory syndrome

NIH: National Institute of Health

Nsp: Non-structural proteins

$\mathbf{N}$ : Nucleocapsid 
Orf: Open reading frame

PHEIC: Public health emergency of international concern

RBD: Receptor-binding domain

$\mathbf{R}_{0}$ : Reproductive number

RdRp: RNA-subordinate RNA polymerase

SARS-CoV-2: Severe acute respiratory syndrome coronavirus 2

TMPS2: Transmembrane protease serine 2

\section{ACKNOWLEDGMENTS}

The authors acknowledged the institute of Microbiology and Department of Pathology, University of Agriculture, Faisalabad.

\section{AUTHOR'S CONTRIBUTIONS}

All authors contributed equally to the idea, writing and correction of the manuscript. All authors read and approved the final version of the manuscript.

\section{FUNDING}

None.

\section{AVAILABILITY OF DATA AND MATERIALS}

Not applicable.

\section{ETHICS APPROVAL AND CONSENT TO PARTICIPATE}

Not applicable.

\section{CONSENT FOR PUBLICATION}

Not applicable.

\section{COMPETING INTERESTS}

The authors declare that they have no competing interests.

\section{REFERENCES}

1. Dhama K, Patel SK, Pathak M, Yatoo MI, Tiwari R, Malik YS, et al. An update on SARS-CoV-2/COVID-19 with particular reference to its clinical pathology, pathogenesis, immunopathology and mitigation strategies. Travel Med Infect Dis. 2020;37:101755. PMID: 32479816. Available from: https://doi.org/10.1016/j.tmaid.2020.101755.

2. Lai CC, Shih TP, Ko WC, Tang HJ, Hsueh PR. Severe acute respiratory syndrome coronavirus 2 (SARS-CoV-2) and coronavirus disease-2019 (COVID-19): The epidemic and the challenges. Int J Antimicrob Agents. 2020;55(3):105924. PMID: 32081636. Available from: https://doi.org/10.1016/j. ijantimicag.2020.105924.

3. Zelaya H, Alvarez S, Kitazawa H, Villena J. Respiratory antiviral immunity and immunobiotics: Beneficial effects on inflammation-coagulation interaction during influenza virus infection. Front Immunol. 2016;7:633. PMID: 28066442. Available from: https://doi.org/10.3389/fimmu.2016.00633.

4. Wang K, Ran L, Yan T, Niu Z, Kan Z, Zhang Y, et al. Anti-TGEV Miller Strain Infection Effect of Lactobacillus plantarum Supernatant Based on the JAK-STAT1 Signaling Pathway. Front
Microbiol. 2019;10:2540. PMID: 31781061. Available from: https://doi.org/10.3389/fmicb.2019.02540.

5. Prompetchara E, Ketloy C, Palaga T. Immune responses in COVID-19 and potential vaccines: Lessons learned from SARS and MERS epidemic. Asian Pacific J Allergy Immunol. 2020;38:1-9. Available from: https://doi.org/10.12932/AP200220-0772.

6. Sohrabi C, Alsafi Z, O'Neill N, Khan M, Kerwan A, Al-Jabir A, et al. World Health Organization declares global emergency: A review of the 2019 novel coronavirus (COVID-19). Int J Surg. 2020;76:71-76. PMID: 32112977. Available from: https://doi. org/10.1016/j.ijsu.2020.02.034.

7. Kannan S, Ali PSS, Sheeza A, Hemalatha K. COVID-19 (Novel Coronavirus 2019)-recent trends. Eur Rev Med Pharmacol. 2020;24(4):2006-2011.

8. Giovanetti M, Benvenuto D, Angeletti S, Ciccozzi M. The first two cases of 2019-nCoV in Italy: Where they come from? J Med Virol. 2020;92:518-521. PMID: 32022275. Available from: https://doi.org/10.1002/jmv.25699.

9. Waki N, Matsumoto M, Fukui Y, Suganuma H. Effects of probiotic Lactobacillus brevis KB290 on incidence of influenza infection among schoolchildren: An open-label pilot study. Lett Appl Microbiol. 2014;59:565-571. PMID: 25294223. Available from: https://doi.org/10.1111/lam.12340.

10. Read J, Bridgen JR, Cummings DA, Ho A, Jewell C. Novel coronavirus 2019-nCoV: early estimation of epidemiological parameters and epidemic predictions. MedRxiv;(10):16-20. Available from: https://doi.org/10.1101/2020.01.23.20018549.

11. Zhao S, Lin Q, Ran J, Musa SS, Yang G, Wang W, et al. Preliminary estimation of the basic reproduction number of novel coronavirus (2019-nCoV) in China, from 2019 to 2020: A datadriven analysis in the early phase of the outbreak. Int J Infect Dis. 2020;92:214-217. PMID: 32007643. Available from: https://doi.org/10.1016/j.ijid.2020.01.050.

12. Rothan HA, Byrareddy SN. The epidemiology and pathogenesis of coronavirus disease (COVID-19) outbreak. J Autoimmun. 2020;109:102433. PMID: 32113704. Available from: https://doi.org/10.1016/j.jaut.2020.102433.

13. Banerjee A, Kulcsar K, Misra V, Frieman M, Mossman K. Bats and coronaviruses. Viruses. 2019;11:7-9. PMID: 30634396. Available from: https://doi.org/10.3390/v11010041.

14. Jin X, Lian JS, Hu JH, Gao J, Zheng L, Zhang YM, et al. Epidemiological, clinical and virological characteristics of 74 cases of coronavirus-infected disease 2019 (COVID-19) with gastrointestinal symptoms. Gut. 2020;69:1002-1009. PMID: 32213556. Available from: https://doi.org/10.1136/gutjnl-2020-320926.

15. Gao QY, Chen YX, Fang JY. 2019 Novel coronavirus infection and gastrointestinal tract. J Dig Dis. 2020;21:125-126. PMID: 32096611. Available from: https://doi.org/10.1111/1751-2980. 12851.

16. Orbach H, Matok I, Gorodischer R, Sheiner E, Daniel S, Wiznitzer $A$, et al. Hypertension and antihypertensive drugs in pregnancy and perinatal outcomes. Am J Obstet Gynecol. 2013;208:301.e1-301.e6. PMID: 23159698. Available from: https://doi.org/10.1016/j.ajog.2012.11.011.

17. Pan Y, Zhang D, Yang P, Poon LLM, Wang Q. Viral load of SARSCoV-2 in clinical samples. Lancet Infect Dis. 2020;20:411-412. Available from: https://doi.org/10.1016/S1473-3099(20)301134.

18. Prince M, Patel V, Saxena S, Maj M, Maselko J, Phillips MR, et al. No health without mental health. Lancet. 2007;370:859-877. Available from: https://doi.org/10.1016/S0140-6736(07)612380.

19. Memish ZA, Perlman S, Van Kerkhove MD, Zumla A. Middle East respiratory syndrome. Lancet. 2020;395:1063-1077. Available from: https://doi.org/10.1016/S0140-6736(19)332210.

20. Chan JFW, Yuan S, Kok KH, To KKW, Chu H, Yang J, et al. A familial cluster of pneumonia associated with the 2019 novel coronavirus indicating person-to-person transmission: a study of 
a family cluster. Lancet. 2020;395:514-523. Available from: https://doi.org/10.1016/S0140-6736(20)30154-9.

21. Xu Z, Shi L, Wang Y, Zhang J, Huang L, Zhang C, et al. Pathological findings of COVID-19 associated with acute respiratory distress syndrome. Lancet Respir Med. 2020;8:420-422. Available from: https://doi.org/10.1016/S2213-2600(20)30076-X.

22. Li R, Lu W, Yang X, Feng P, Muqimova O, Chen X, Wei, G. Prediction of the Epidemic of COVID-19 Based on Quarantined Surveillance in China 2020. medRxiv. 2020;2020(8):234-241. Available from: https://doi.org/10.1101/2020.02.27.20027169.

23. Wang W, Tang J, Wei F. Updated understanding of the outbreak of 2019 novel coronavirus (2019-nCoV) in Wuhan, China. J Med Virol. 2020;92:441-447. PMID: 31994742. Available from: https://doi.org/10.1002/jmv.25689.

24. Lin L, Jiang X, Zhang Z, Huang S, Zhang Z, Fang Z, et al. Gastrointestinal symptoms of 95 cases with SARS-CoV-2 infection. Gut. 2020;69:997-1001. PMID: 32241899. Available from: https://doi.org/10.1136/gutjnl-2020-321013.

25. Livingston E, Bucher K, Rekito A. Coronavirus Disease 2019 and Influenza 2019-2020. JAMA - J Am Med Assoc. 2020;323:1122. PMID: 32207769. Available from: https://doi. org/10.1001/jama.2020.2633.

26. Li X, Geng M, Peng Y, Meng L, Lu S. Molecular immune pathogenesis and diagnosis of COVID-19. J Pharm Anal 2020;:8;10:102-108. PMID: 32282863. Available from: https://doi. org/10.1016/j.jpha.2020.03.001.

27. Gao Q, Hu Y, Dai Z, Xiao F, Wang J, Wu J. The epidemiological characteristics of 2019 novel coronavirus diseases (COVID-19) in Jingmen, Hubei, China. Medicine. 2020;99(23):e20605. Available from: https://doi.org/10.1097/ md.0000000000020605.

28. Sencio V, Barthelemy A, Tavares LP, Machado MG, Soulard D, Cuinat $C$, et al. Gut Dysbiosis during Influenza Contributes to Pulmonary Pneumococcal Superinfection through Altered Short-Chain Fatty Acid Production. Cell Rep. 2020;30:29342947.e6. PMID: 32130898. Available from: https://doi.org/10. 1016/j.celrep.2020.02.013.

29. Pullano G, Pinotti F, Valdano E, Boelle PY, Poletto C, Colizza V. Novel coronavirus (2019-nCoV) early-stage importation risk to Europe, January 2020. Eurosurveillance. 2020;25(4):2000057. PMID: 32019667. Available from: https://doi.org/10.2807/ 1560-7917.ES.2020.25.4.2000057.

30. Bell D, Roberton S, Hunter PR. Animal origins of SARS coronavirus: Possible links with the international trade in small carnivores. Philos Trans R Soc B Biol Sci. 2004;359:1107-1114. PMID: 15306396. Available from: https://doi.org/10.1098/rstb. 2004.1492.

31. Wan Y, Shang J, Graham R, Baric RS, Li F. Receptor Recognition by the Novel Coronavirus from Wuhan: an Analysis Based on Decade-Long Structural Studies of SARS Coronavirus. J Virol. 2020;94:973-974. PMID: 31996437. Available from: https:// doi.org/10.1128/JVI.00127-20.

32. Romero JR. Enteroviruses. International Encyclopedia of Public Health (Second Edition). 2017;2016(10):474-478. PMID: 28591308. Available from: https://doi.org/10.1016/B978-0-12803678-5.00131-4

33. Turner RB, Woodfolk JA, Borish L, Steinke JW, Patrie JT, Muehling $L M$, et al. Effect of probiotic on innate inflammatory response and viral shedding in experimental rhinovirus infection - A randomised controlled trial. Benef Microbes. 2017;8(2):207-215. PMID: 28343401. Available from: https: //doi.org/10.3920/BM2016.0160.

34. Abdulamir AS, Hafidh RR. The possible immunological pathways for the variable immunopathogenesis of COVID-19 infections among healthy adults, elderly and children. Electron J Gen Med. 2020;17(4):em202. Available from: https: //doi.org/10.29333/ejgm/7850.

35. Szajewska H, Kołodziej M, Gieruszczak-Białek D, Skórka A, Ruszczyński M, Shamir R. Systematic review with meta- analysis: Lactobacillus rhamnosus GG for treating acute gastroenteritis in children - a 2019 update. Aliment Pharmacol Ther. 2019;49(11):1376-1384. PMID: 31025399. Available from: https://doi.org/10.1111/apt.15267.

36. Reisinger A, Stadlbauer V. Letter on synbiotics modulate gut microbiota and reduce enteritis and ventilator-associated pneumonia in patients with sepsis: A randomized controlled trial. Crit Care. 2019;23(1):56. PMID: 30782178. Available from: https://doi.org/10.1186/s13054-019-2319-7.

37. Di Pierro F. A possible probiotic (S. salivarius K12) approach to improve oral and lung microbiotas and raise defenses against SAR S-CoV-2. Minerva Med. 2020;111(3):281-283. PMID: 32255312. Available from: https://doi.org/10.23736/S00264806.20.06570-2.

38. Sanders ME, Merenstein DJ, Ouwehand AC, Reid G, Salminen $\mathrm{S}$, Cabana MD, et al. Probiotic use in at-risk populations. J Am Pharm Assoc. 2016;56(6):680-686. PMID: 27836128. Available from: https://doi.org/10.1016/j.japh.2016.07.001.

39. 42 :. Pregliasco F, Anselmi G, Fonte L, Giussani F, Schieppati $S$, Soletti L. A new chance of preventing winter diseases by the administration of synbiotic formulations. J Clin Gastroenterol. 2008;42(Suppl 3 Pt 2):S224-S233. PMID: 18685511. Available from: https://doi.org/10.1097/MCG.0b013e31817e1c91.

40. Mackay IM, Arden KE. MERS coronavirus: Diagnostics, epidemiology and transmission. Virol J. 2015;12:222. PMID: 26695637. Available from: https://doi.org/10.1186/s12985015-0439-5.

41. Shoaib A, Xin L, Xin Y. Oral administration of Lactobacillus acidophilus alleviates exacerbations in Pseudomonas aeruginosa and Staphylococcus aureus pulmonary infections. Pak J Pharm Sci. 2019;32:1621-1630.

42. Namba K, Hatano M, Yaeshima T, Takase M, Suzuki K. Effects of bifidobacterium longum BB536 administration on influenza infection, influenza vaccine antibody titer, and cellmediated immunity in the elderly. Biosci Biotechnol Biochem. 2010;74(5):939-945. PMID: 20460726. Available from: https: //doi.org/10.1271/bbb.90749.

43. Luoto R, Ruuskanen O, Waris M, Kalliomäki M, Salminen S, Isolauri E. Prebiotic and probiotic supplementation prevents rhinovirus infections in preterm infants: A randomized, placebocontrolled trial. J Allergy Clin Immunol. 2014;133(2):405-413. PMID: 24131826. Available from: https://doi.org/10.1016/j.jaci. 2013.08.020.

44. Kumar V, Baruah K, Nguyen DV, Smagghe G, Vossen E, Bossier P. Phloroglucinol-mediated $\mathrm{Hsp} 70$ production in crustaceans: Protection against Vibrio parahaemolyticus in Artemia franciscana and Macrobrachium rosenbergii. Front Immunol. 2018;9:1091. PMID: 29872432. Available from: https://doi.org/ 10.3389/fimmu.2018.01091.

45. Lehtoranta L, Kalima K, He L, Lappalainen M, Roivainen M, Närkiö $M$, et al. Specific probiotics and virological findings in symptomatic conscripts attending military service in Finland. J Clin Virol. 2014;60(3):276-281. PMID: 24793963. Available from: https://doi.org/10.1016/j.jcv.2014.03.021.

46. Jeyanathan M, Afkhami S, Smaill F, Miller MS, Lichty BD, Xing Z. Immunological considerations for COVID-19 vaccine strategies. Nature Reviews Immunology. 2020;20(10):615-632. PMID: 2887954. Available from: 10.1038/s41577-020-00434-6.

47. Rautava S, Salminen S, Isolauri E. Specific probiotics in reducing the risk of acute infections in infancy - A randomised, double-blind, placebo-controlled study. Br J Nutr. 2009;101(11):1722-1726. PMID: 18986600. Available from: https://doi.org/10.1017/S0007114508116282.

48. Goldenberg J, Ma S, Saxton J, Al. E. Probiotics for the prevention of Clostridium difficile- associated diarrhea in adults and children ( Review ) SUMMARY OF FINDINGS FOR THE MAIN COMPARISON. Cochrane Database Syst Rev. 2017;(12):CD006095. Available from: https://doi.org/10.1002/ 14651858.CD006095.pub4. 